\title{
MORPHO-ANATOMICAL AND PHYSIOLOGICAL CHANGES IN GRAPEVINE LEAVES EXPOSED TO ATMOSPHERIC FLUORIDE AND SULFUR DIOXIDE POLLUTION
}

\author{
RHIMI, N. ${ }^{1}$ - BEN AHMED, C..$^{1 *}$ - ELLOUMI, N. ${ }^{2}-$ ATHAR, H. R. ${ }^{3}-$ NOREEN, S. ${ }^{3}-$ \\ ASHRAF, M. ${ }^{4}-$ BEN ABDALLAH, F. ${ }^{1}-$ BEN NASRI-AYACHI, M. $^{5}$ \\ ${ }^{1}$ Laboratory of Plant Ecology, Faculty of Sciences of Sfax, B.P. 1171, 3000 Sfax, Tunisia \\ ${ }^{2}$ Laboratory of Water, Energy and Environment, Sfax University, Higher Institute of \\ Biotechnology of Sfax, Tunisia \\ ${ }^{3}$ Institute of Pure and Applied Biology Bahauddin Zakariya University, Multan 60800, Pakistan \\ ${ }^{4}$ Pakistan Science Foundation, Islamabad, Pakistan \\ ${ }^{5}$ Laboratory of Applied and Fundamental Botany, Faculty of Sciences of Tunis, Tunisia \\ *Corresponding author \\ e-mail: benahmed.c@gmail.com \\ (Received $27^{\text {th }}$ Apr 2016; accepted $22^{\text {nd }}$ Jul 2016)
}

\begin{abstract}
A comparative study on the effects of air fluoride and sulphur dioxide pollution on a local vine (Vitis vinefera L.) cultivar "Asli" growing in the vicinity of a factory producing phosphate fertilisers in the southern suburb of Sfax region was investigated. The chemical analysis of both peripheral and central necrotic leaf round slices reveals a preferential accumulation of fluoride, as well as calcium in leaf margins and tips. However, central leaf areas seem to accumulate both sulfur and magnesium. These findings confirm the involvement of these two elements not only in the detoxification of fluoride as $\mathrm{CaF}_{2}$ and $\mathrm{MgF}_{2}$, but also in regulating metabolic pathways. On the other hand, net photosynthesis is maintained at appropriate levels, while 30 to $40 \%$ of leaf surface are altered by necrosis. Furthermore, several structural changes are revealed in polluted leaves. Indeed, the decrease of leaf density is due probably to (i) a decrease in intercellular spaces, (ii) a decline of vascular bundles number and (iii) a gradual sclerotization of collenchyma cells occurring jointly with a thickening of their walls.
\end{abstract}

Keywords: gaseous fluoride, fruit trees, ion accumulation, necrotic spots, collenchyma cells

\section{Introduction}

Fluoride compounds and sulphur dioxide $\left(\mathrm{SO}_{2}\right)$ are among the most important phytotoxic air pollutants and prevalent near to industrial activity areas such as fertilizer factories, brick kilns, ceramic manufacturing etc (Bell and Treshow, 2002). Generally, industries are constructed in rural areas or outskirts of the cities near to agricultural activity areas. Air pollutants emitted from industrial activity areas become dispersed in surrounding and deposited on plant leaf surfaces in particulate form or gaseous form (Baillie et al., 2016; Baunthiyal et al., 2014). Despite grapevine (Vitis vinefera L.) sensitivity to air pollutants (Doley, 1986; Leece et al., 1986; Murray, 1984), some ecotypes of "Asli" local cultivars are still surviving in the area surrounding the SIAPE (factory producing phosphoric acid and phosphate fertilizers) located in the southern suburb of Sfax city (Tunisia) (Fig. 1). Air pollutants emitted by the SIAPE chimneys factory are mainly fluoride compounds, sulphur dioxide and particles (Azri et al., 2002; Ben-Abdallah and Boukhris, 1990). On the other hand, 
Ben Abdallah (2007) found that fluoride (F) concentration in the air surrounding the factory ranged from $0.3-0.68 \mu \mathrm{g} \mathrm{m}^{-3}$. In some studies, plant responses of plants to air pollution were carried out on plants by exposing them to long or short term fumigations (Davieson et al., 1990; Doley, 1986; Murray and Wilson, 1988) or in hydroponics (Stevens et al., 1998) or by analyzing plants growing near to source of pollution industry (Abdallah et al., 2006; Elloumi et al., 2003; Jha et al., 2008; Zwiazek and Shay, 1987). It has been reported that plants can uptake fluoride through roots (Chakrabarti et al., 2013; Telesiński et al., 2011). However, fluoride mainly entered into plants via stomatal apparatus thus affecting transpiration and photosynthesis or caused necrosis in leaves (Jha et al., 2008). In addition to leaf injuries, air pollutants including $\mathrm{F}$ and $\mathrm{SO}_{2}$ cause various physiological disorders including reduction in photosynthesis and photosynthetic pigments, carbohydrate metabolism, membrane dysfunction and anatomical cellular structures (Ali et al., 2008; Baunthiyal et al., 2014; Mesquita et al., 2010; Telesiński et al., 2011). However, detailed information about changes in anatomical and cellular structures with respect to their mechanisms of accumulation and tolerance is scarce. Such information can help us in using plant species for bio-monitoring (Festy, 2001) as such plant responses depend on type of species, type of cultivar used, plant age, climatic conditions and the distance from the pollution source (Elloumi et al., 2003). The major purpose of the present study was to appraise the combined effects of both fluoride and sulphur dioxide pollution on accumulation of mineral nutrients and anatomical traits of local Asli vine cultivar grown in Sfax city (Tunisia). A secondary objective of the present study was to assess the role of $\mathrm{Ca}$ and $\mathrm{Mg}$ in avoiding and / or mitigating pollutant toxicity. In addition, up to what extent different leaf anatomical characteristics were modulated or damaged by these air pollutants in an arid region of Tunisia.

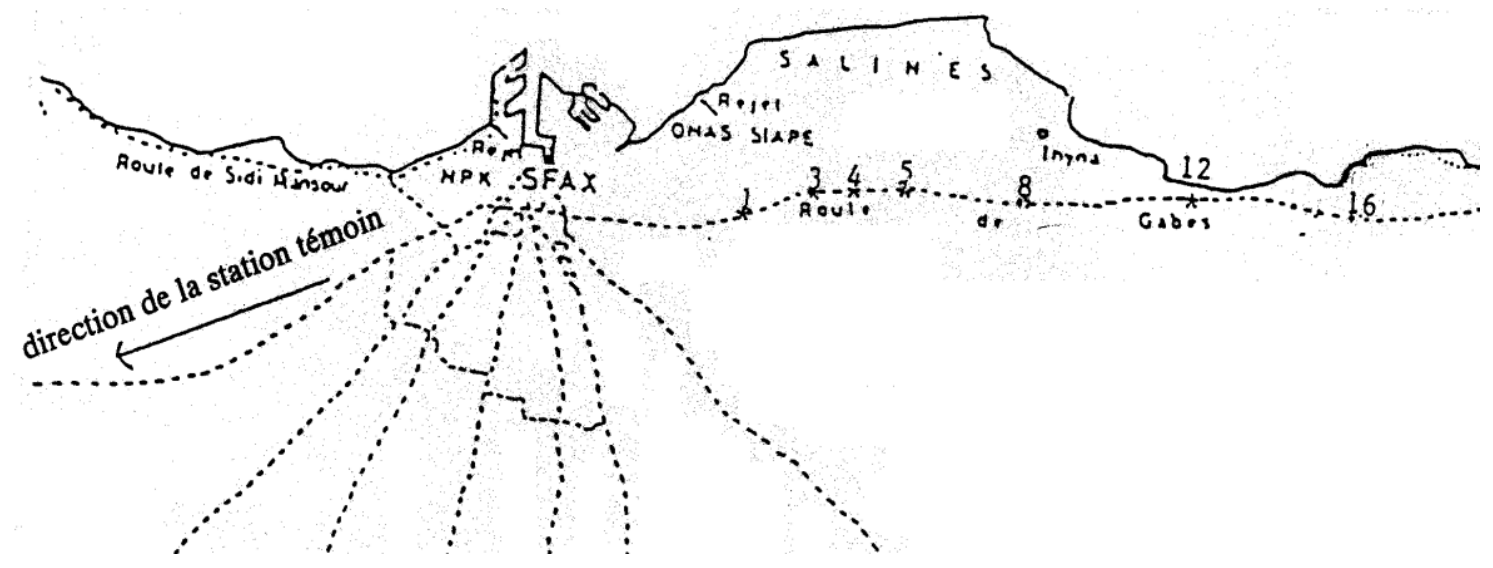

Figure 1. Map of study area in Sfax, Tunisia

\section{Materials and Methods}

\section{Description of study area}

The study area is $20 \mathrm{~km}$ wide Mediterranean coastal low land lined with 100-meter high peaks. It is submitted both to continental dry winds and to highly humid sea coastal winds. The prevailing winds from the southeastern sector have a frequency of $(25.5 \%)$, and those of the southwestern sector appear with a frequency of about $16.25 \%$. However, northwest and northeast winds occur with intermediate 
frequencies. The average total year rainfall is $210 \mathrm{~mm}$, the average minimum temperature of the coldest month (January) is $6.5^{\circ} \mathrm{C}$ and the average maximum temperature of the hottest month (August) is $31^{\circ} \mathrm{C}$. Most of the total annual rainfall is mostly occurring from October to December; the dry period is during June-September.

\section{Sampling techniques}

The 20-year old local vines (Vitis vinefera L.) growing in a loamy sand soil which were approximately $0.5 \mathrm{~km}$ and $30 \mathrm{~km}$ away from the polluting factory "SIAPE factory" were marked as polluted and control plants. Similarities between polluted and non polluted sites were verified by particle size analysis. Ninety (90) leaf samples from three plants of the cultivar were taken from branches located in the upper median and lower portions of the vine tree which were facing and exposed to the factory fume. Non-affected leaf samples were collected from non-polluted land plots situated $30 \mathrm{~km}$ away the factory. Aerial parts of vine that are located above the $12^{\text {th }}$ node of the shoot were taken. Samples were collected from polluted and non-polluted sites during the grapevine growing season (June, July and August 2009).

To determine leaf pollutant sites, we selected only grape leaves exhibiting at the same time central and marginal necroses. Owing to their available great leaf surfaces, 90 grapevine leaves, with 30 to $40 \%$ of necrotic leaf area, were cut into leaf marginal and leaf central necrotic pieces. The same leaf marginal and central pieces were also used to determine the concentration of $\mathrm{F}, \mathrm{Ca}^{2+}, \mathrm{Mg}^{2+}$ and $\mathrm{P}$.

The leaf marginal necrosis was evaluated throughout the growing season (from May to August) of the leaves of "Asli" cultivar. Photosynthesis measurements were performed after the estimation of leaf necrose percentage according to Mabrouk and Carbonneau (1996) method. Necrotic peripheral slices of leaves were distributed into classes according to percent necrotic area (Table 1). Control or non-affected leaves were also cut into leaf marginal and central area and grouped into classes along with affected leaves.

Table 1. Distribution of classes in function of percentage of leaf necroses.

\begin{tabular}{ccccccc}
\hline \multicolumn{7}{c}{ Percentage of leaf necroses } \\
\hline Classes & Control & 0 & $10-20$ & $30-40$ & $50-60$ & $>60$ \\
\hline
\end{tabular}

\section{Photosynthesis measurements}

Leaf net photosynthesis was measured in the field under ambient environmental conditions between 9:30 and 10:00 am using a portable gas exchange system (IRGA, CID 301 PS, Vancouver USA). The measurements were made on leaves that remain attached to the mother plant, occupying the $10^{\text {th }}$ to the $12^{\text {th }}$ shoot node. All measurements for gas exchange were taken on sunny days with $1500 \mu \mathrm{mol} \mathrm{m}^{-2} \mathrm{~s}^{-1}$ light intensity. The PAR was measured directly by the infrared gas exchange analyzer system. The average leaf temperature during the experimental period was of $34{ }^{\circ} \mathrm{C} \pm$ $2.55^{\circ} \mathrm{C}$. All measurements of gas exchange characteristics were measured on grapevine plants at both locations on with a difference of one day with same diurnal conditions. If there was any significant change in light or weather conditions, the measurements were taken on the next day but under similar diurnal conditions. 


\section{Fluoride, sulphur, calcium and magnesium analyses}

For fluoride analysis, different plant tissues (leaf blade, leaf stalk and internodes) were oven-dried at $70{ }^{\circ} \mathrm{C}$ for 72 hours. Oven dried leaf material were ground to make powder. Leaf powder was re-dried prior to weighing sub-samples for analysis. Fluoride concentrations were determined using the potentiometric technique described by Rhimi et al. (2011). Sulphur was determined by the turbidimetric method of (Blanchar et al., 1965), the detection limit of which is about $10 \mathrm{ppm}$ with a RSD of $0.41 \%$.

After digesting plant powder with nitric and perchloric acids $(2 \mathrm{v} / 1 \mathrm{v}), \mathrm{Ca}^{2+}$ and $\mathrm{Mg}^{2+}$ were determined by the atomic absorption spectrophotometry technique with polarized Zeeman (HITACHI, Z-6100).

\section{Anatomical sections}

Fresh polluted and non polluted grape leaves were taken and fixed during 24 hours in Formalin - Acetic - Alcohol mixture (FAA) according to the fixation procedure described by Sass (1958). The fixed material was rinsed with water and then divided into two batches. The first one was dehydrated in alcohol and included in paraffin, cut and stained by the triple stain (Safranin, Heidenhain's and blue aniline). The second batch was cut by a freezing microtome and stained with aceto-carmin (Locquin and Langeron, 1978). Freezing and serial cross sections were observed under a light Reichert LKB microscope equipped with a camera.

\section{Statistical analyses}

Statistical analyses were performed with the SAS package (Statistical Analysis System, version 6.12, Cary, NC, USA) using both Duncan multiple range and Student Tests at the $5 \%$ significance level.

\section{Results}

\section{Morphological responses}

Our regular field observations in the polluted area allowed us to recognize various expressions of damage caused to the local vines growing in the vicinity of the factory. As shown in Fig. 2, two types of leaf necroses were observed: marginal necroses of brick red colour, occupying lobes extremities and central necroses occupying inter vein leaf blade spaces as few scattered circular red spots. Whereas the formers are very frequent and present in nearly all the vine leaves exposed to the factory smoke; the latter's are infrequent and appear especially on old leaves.

For the studied cultivar, necrotic tissues are separated from healthy ones by a dark violet borderline (Fig. 2). As time advances, necroses continue to invade the leaf surface. New necrotic tissues are limited by a new borderline less attenuated than the first one until obtaining concentric halos of necrotic zones giving the leaf margin a mosaic aspect (Fig. 1). 


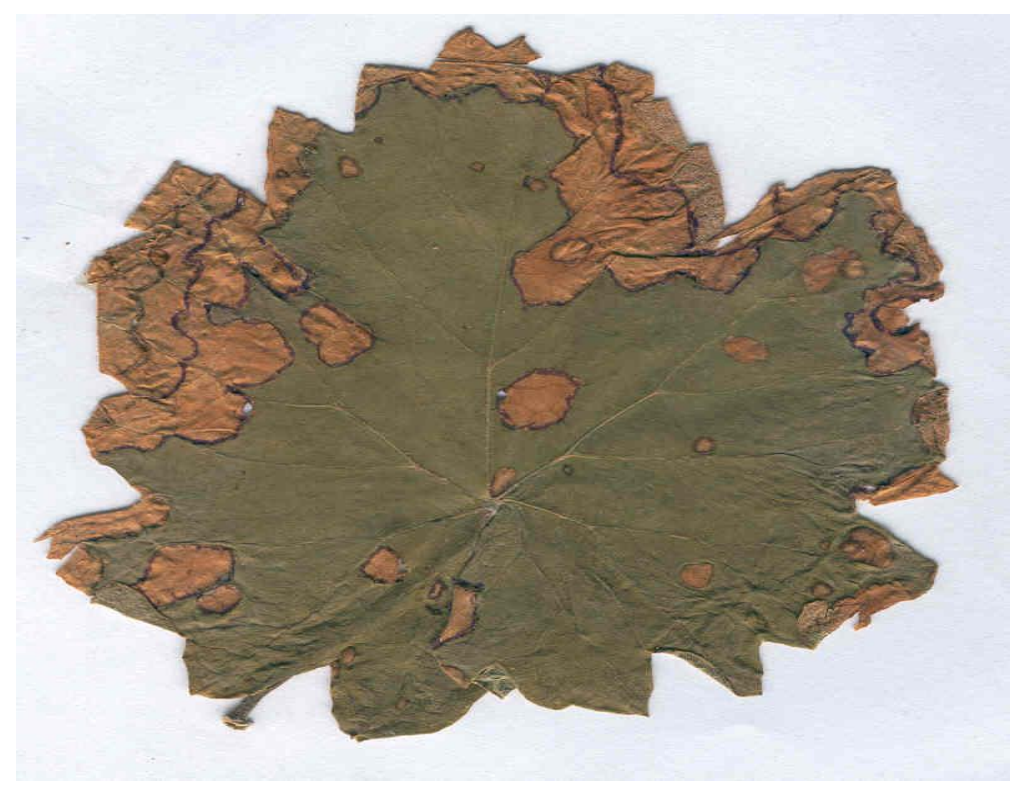

Figure 2. General pattern of necrotic areas in the leaves of grapevine cv. Asli affected by factory fumes

\section{Observation of anatomical sections}

In comparison with control (Fig. 3, A-D), grapevine leaves from polluted area showed a decrease in number of upper and lower epidermal cells (Fig. 4, E-M), thickening in epidermal cuticle, thickening in cell walls of collenchyma cells at both sides of leaf midrib, an increase in sclerotisation of collenchyma cells.
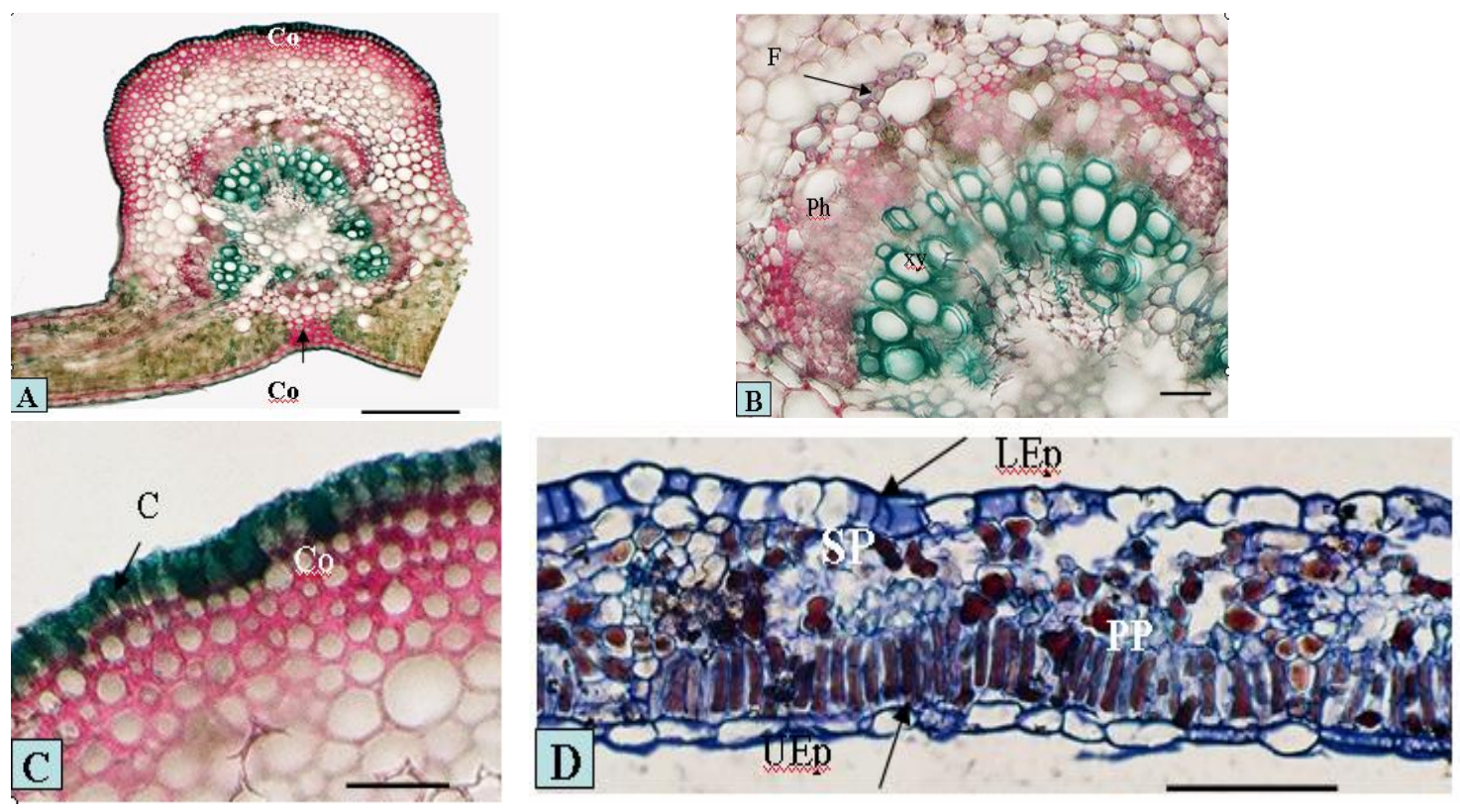

Figure 3. (A) Transverse section, of control grape leaves, including the midrib, scale 1 bar = $100 \mu \mathrm{m}$. (B) Detail of the midrib vascular tissues, scale 1 bar $=10 \mu \mathrm{m} .(C)$ Detail of the collenchyma, scale 1 bar $=20 \mu \mathrm{m}$. (D) Transverse section through the leaf blade. 1 bar $=100$ um. $C=$ cuticle $;$ Co = collenchyma $;$ LEp = lower epidermis; $P h=$ phloem; $P P=$ palisade parenchyma; $S P=$ spongy parenchyma; UEp = upper epidermis; $X y=x y l e m$. 

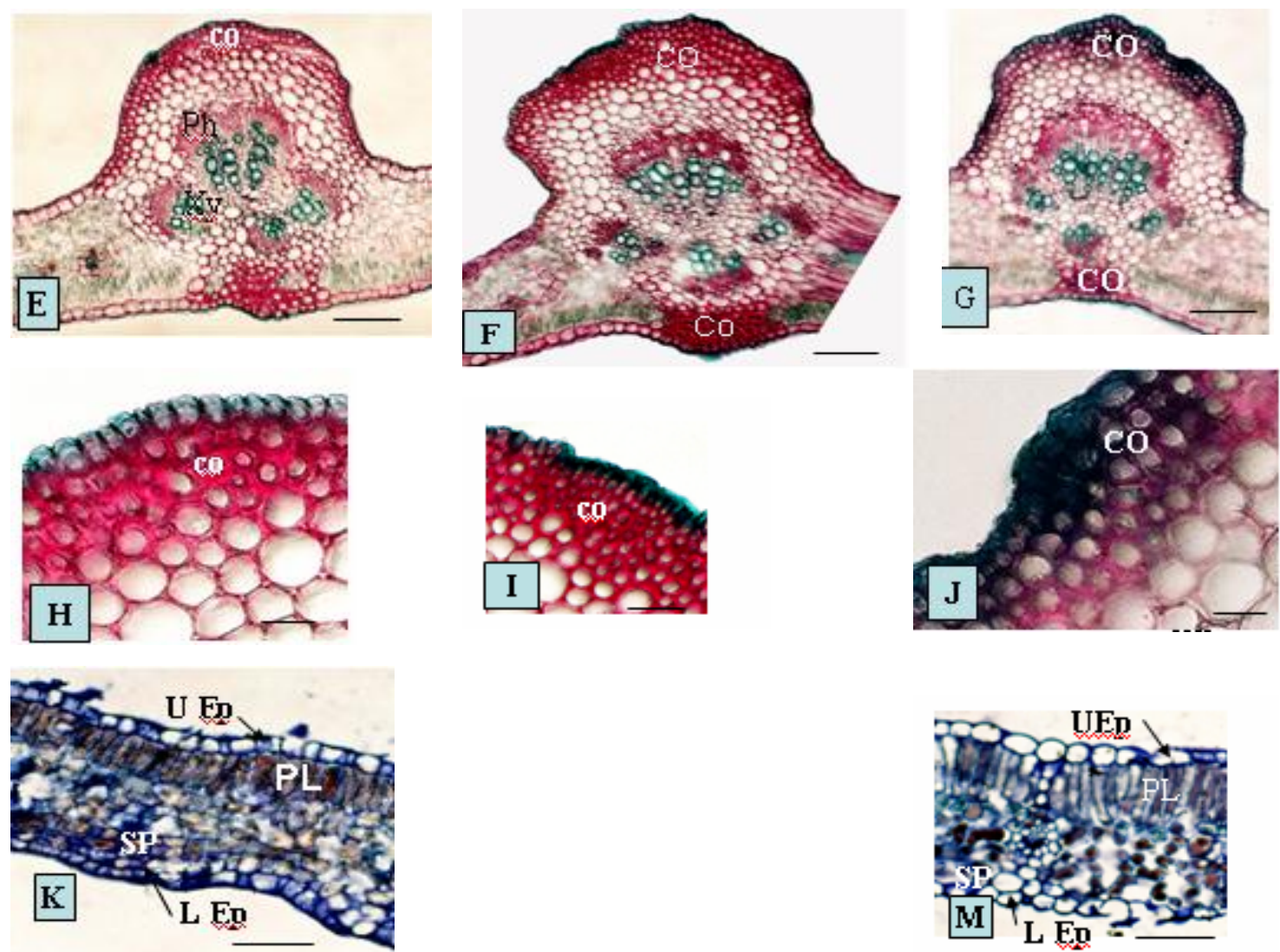

Figure 4. Transverse sections of polluted grape leaves. (E-G) Detail of midribs, scale 1 bar = $100 \mu \mathrm{m} .(H-J)$ Detail of the collenchyma. Note both its thickeness and sclerification with respect to the control, scale 1 bar $=20 \mu \mathrm{m} .(K-M)$ Transverse section through the leaf blade, scale 1 bar $=100 \mu \mathrm{m} . \mathrm{C}=$ cuticle $; \mathrm{Co}=$ collenchyma $;$ LEp = lower epidermis; $\mathrm{Ph}=$ phloem $; \mathrm{PP}=$ palisade parenchyma; $S P=$ spongy parenchyma; UEp = upper epidermis; Xy =xylem.

\section{Fluorine and sulphur distribution in different plant parts}

Analyses of necrotic and central round leaf slices showed a significant increase in fluoride $(\mathrm{F})$ accumulation in the necrotic leaf areas. On the other hand, the F content of the central leaf parts including the main veins were similar to that in control leaves (Fig. $5)$. Both leaf stalks and internodes accumulated lower $\mathrm{F}$ as compared to that in central or marginal areas of leaf from non-polluted and polluted area (Table. 2; Fig. 5).

Table 2. Fluoride $\left(\mu g \cdot g^{-1} D W\right)$ content of leaf stalk and internodes of grapevine cv. Asli from polluted and non-polluted areas during two different periods.

\begin{tabular}{ccccc}
\hline & \multicolumn{2}{c}{ May 15 th } & \multicolumn{2}{c}{ August 15 th } \\
\hline & \multicolumn{2}{c}{ F $^{-}$} & \multicolumn{2}{c}{ F $^{-}$} \\
\hline Area & Control & Polluted & Control & Polluted \\
\hline Leaf stalk & $5.7 \pm 0.1$ & $6.1 \pm 0.6^{*}$ & $6.1 \pm 0.4$ & $6.5 \pm 0.2^{\mathrm{NS}}$ \\
\hline Internode & $0.71 \pm 0.05$ & $0.74 \pm 0.07^{\mathrm{NS}}$ & $0.81 \pm 0.05$ & $1.29 \pm 0.06^{* * *}$ \\
\hline
\end{tabular}

Fluoride contents Vs controls $* * * \mathrm{p} \leq 0.001, * * \mathrm{p} \leq 0.01, * \mathrm{p} \leq 0.05$ NS: non significant $(\mathrm{n}=10)$. 


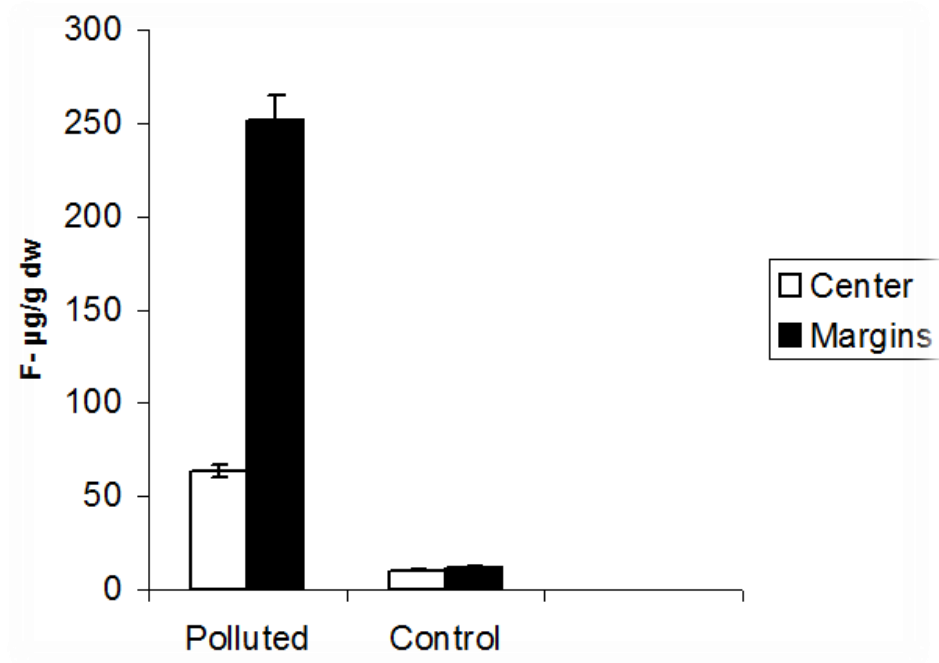

Figure 5. Fluoride contents ( $\mu \mathrm{g} F / g d w)$ in the center and in leaf margins of grapevine $c v$. Asli from non-polluted and polluted areas. Means of 10 replicates and confidence intervals at $5 \%$.

The chemical analyses of central leaf necrotic round slices showed high leaf sulphur content, as compared to control ones (Fig. 6). However, contents of sulphur in leaf margins and fluoride in the centre were not significantly higher than those of controls (Figs. 5, 6).

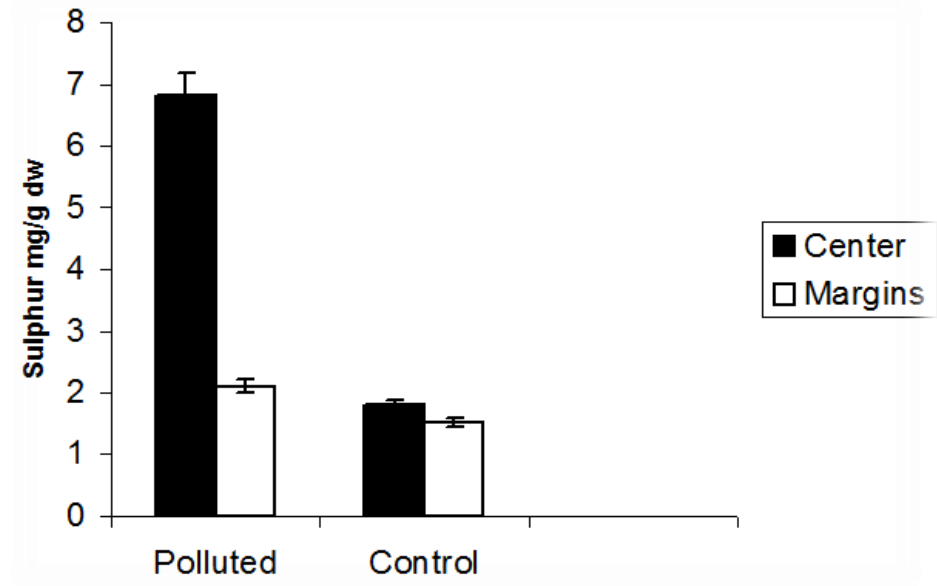

Figure 6. Sulphur contents ( $\mathrm{mg} S \mathrm{~g} \mathrm{dw}$ ) in the center and in leaf margins of grapevine cv. Asli from non-polluted and polluted areas. Means of 10 replicates and confidence intervals at $5 \%$.

In the present study, a significant increase in fluoride accumulation was recorded in the necrotic peripheral round leaf slices. However, central parts of grapevine leaves including the main veins or midrib accumulated lower amount of fluoride (Fig. 5). The leaf stalks and internodes accumulated low fluoride (i.e. 1-6 $\mu \mathrm{g} / \mathrm{g} \mathrm{dwt}$ ) throughout the growing season (Table 2) as compared to that in leaf lamina (50-250 $\mu \mathrm{g} / \mathrm{g} \mathrm{dwt}$; Fig. 5). These results showed the preferential accumulation of fluorine in leaf tissues extremities. 
Besides, the accumulation of fluorine in coincidence with the appearance of peripheral grape leaf necroses suggest the existence of an external mechanism of fluoride sequestration allowing the exclusion of some elements as fluorine at leaf extremity level. Indeed, the restriction of damages to the leaf margins allows the plant to keep a great proportion of leaf surface intact and therefore, to maintain photosynthetic activity at appropriate levels. Such mechanism would explain the ability of this species to photosynthesize, even when the leaf surface was damaged up to $30 \%$ (Table 3).

The chemical analyses of central leaf necrotic round slices showed high leaf sulphur content, compared to control (Fig. 6). For the same grape leaf exhibiting both marginal and inter-vein central necroses, contents of sulphur in margins and fluoride in the centre were not significantly higher than those of controls (Fig. 5, 6). These findings confirm that inter-vein central necroses are probably due to $\mathrm{SO}_{2}$, whereas marginal leaf necroses are typical of fluoride compounds effects.

\section{Leaf calcium and magnesium distribution and photosynthesis of healthy leaf areas}

As also seen in Fig. 7, the mineral analyses of the central and necrotic grape leaf areas reveal high $\mathrm{Ca}$ and $\mathrm{F}$ concentrations in the leaf margins. The polluted grapevine seems to retain more $\mathrm{Mg}$ in the central leaf areas than in the leaf margins. As indicated in Table 3, photosynthesis of central (healthy) leaf areas decreased as the percentage of leaf necroses increased and that the plant could still photosynthesize while 30 to $40 \%$ of its leaf surface was necrotic. However, when $60 \%$ or more of the leaf surface was damaged, and there was less than $40 \%$ of healthy leaf area, low net photosynthesis of the central leaf area was observed (Table 3).

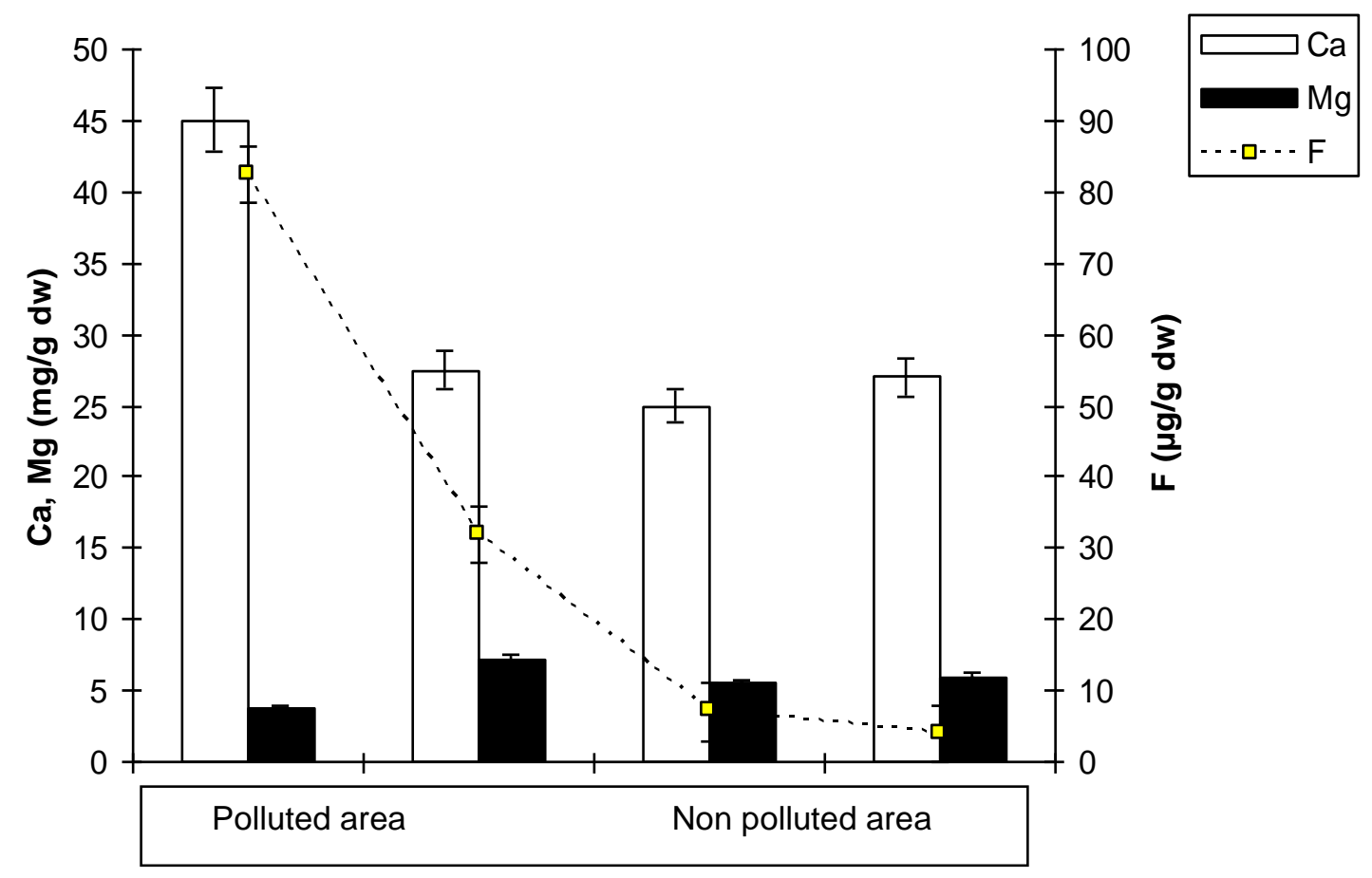

Figure 7. Fluoride, calcium and magnesium concentrations in central and necrotic leaf area of grapevine cv. "Asli" from polluted and non polluted areas. Means of 10 replicates and confidence intervals at 5\%. 
Table 3. Fluoride content $\left(\mu \mathrm{g} \cdot \mathrm{g}^{-1} \mathrm{DW}\right)$ and net photosynthetic rate $\left(\mu \mathrm{mol} \mathrm{m} \mathrm{m}^{-2} \mathrm{~s}^{-1}\right)$ healthy and necrotic areas of grapevine leaves.

\begin{tabular}{ccccccc}
\hline \multicolumn{7}{c}{ Percentage of leaf necroses (\%) } \\
\hline & Control & 0 & $10-20$ & $30-40$ & $50-60$ & 60 \\
\hline Classes & $\mathrm{CT}$ & $\mathrm{C} 0$ & $\mathrm{Cl}$ & $\mathrm{C} 2$ & $\mathrm{C} 3$ & $\mathrm{C} 4$ \\
\hline $\mathrm{F}(\mathrm{n}=10)$ & $17.7 \pm 1.7$ & $24.0 \pm 2^{* *}$ & $36.5 \pm 2.2^{* * *}$ & $64.7 \pm 3.4^{* * *}$ & $83.4 \pm 5,5^{* * * *}$ & $117.4 \pm 8.2^{* * *}$ \\
\hline $\mathrm{Pn}(\mathrm{n}=19)$ & $14.1 \pm 1.1$ & $\underline{13.8 \pm 1.2}^{\mathrm{NS}}$ & $\underline{12.16 \pm 1.34^{+++}}$ & $\underline{10.24 \pm 1.17^{+++}}$ & $\underline{8.3 \pm 1.7^{+++}}$ & ${\underline{6.0 \pm 1.0^{+++}}}$
\end{tabular}

Fluoride content vs controls***p $<0,001, * * \mathrm{p}<0,01(\mathrm{n}=10)$; net photosynthesis vs controls $+++\mathrm{p}<0.001$

NS: non significant $(n=19)$.

\section{Discussion}

In the present study, regular field follow-up in the polluted area allowed us to recognize various expressions of damage caused to vine tree. For example, severe fluoride injuries to vine tree, in the form of necrosis of brick red color at leaf margins and tip burn were detected. In addition, necrosis in the centeral region of leaf was found as few scattered circular red spots. These findings are similar to those of Miller (1992) who reported that brick-red marginal necroses occupying lobes extremities of leaf grapevine represent the symptoms of fluorine pollution, whereas central necroses are the symptoms of $\mathrm{SO}_{2}$ pollution. In the present study, necrotic tissues are separated from healthy ones by a dark violet borderline that consists of anthocyanin pigments. In an earlier study, it is suggested that anthocyanins accumulation in vegetative tissues of plants is an indicator of environmental stress (Fornasiero, 2001), which could be first line of defense to limit damage at leaf margins (Ben Abdallah, 2007). Our previous works demonstrated that the number of necrotic halos could be useful to estimate, within Vitis vinifera species, the degree of sensitivity to pollution (Ben Abdallah et al., 2006).

In some of earlier studies it has been shown that species resistant to air pollution are those accumulating fluoride without showing any symptom of $\mathrm{F}^{-}$toxicity or growth restrictions (Baunthiyal et al., 2014; Ben-Abdallah and Boukhris, 1990; Fornasiero, 2001). In addition, some tolerant species are those exhibiting specific symptoms of $\mathrm{F}^{-}$ toxicity and still surviving in the polluted area. For example, our histochemical study shows that several structural changes were recorded such as (i) a decrease in the size of epidermal cells and the number of vascular bundles with time, (ii) an extension and tightening of palisade parenchyma cells. Decrease in epidermal cells in both upper and lower epidermis is one of the reasons of decrease in leaf thickening due to stress (Fornasiero, 2001). From the data for histochemical studies of fluoride injured plants from the present study, it is suggested that fluoride toxicity caused the damage to spongy mesophyll cells and lower epidermis, and then toxicity spread within the leaf. This argument can be supported by some of similar earlier studies on jack pine (Pinus banksiana L.) (Zwiazek and Shay, 1987), Avena sativa and Lycopersicon esculentum (Stevens et al., 1998). However, the gradual sclerotisation of collenchyma cells due to fluoride accumulation suggested that a wall thickening mechanism to protect leaf cells from injury and death is present in nearby cells. This argument can be supported by the fact that in angiospermic plants wall thickening, lignifications, and neo-synthesis of xylem cells are involved in plant defense mechanism against fungal invasion (Nicole et al., 1992). In the present study, fluoride become accumulated in the necrotic peripheral regions of leaf slices as compared to leaf central parts. These results can be explained in view of the findings of Rhimi et al. (2011) who found lower accumulation of fluoride in 
non-necrotic tissues and suggested that necroses would not appear unless certain concentrations were reached in leaf tissues. Thus, toxicity of fluoride depends on amount of fluoride accumulation.

While examining the fluorine pathway in plant tissues, Fornasiero (2001) reported that fluoride enters the leaf by diffusion through the stomata, and dissolves in the humid spaces of sub stomatal cavity. After that, the ions are translocated with the transpiration stream to sites of greatest evaporation, which are usually margins and tips where concentrated $\mathrm{F}^{-}$amounts would cause the first signs of damage, such as necroses and burns (Eliftheriou and Tsekos, 1991). In view of these reports, we would suggest that apical and marginal necroses are specific and typical of fluoride compounds. In addition, a mechanism that limits fluorine at leaf margins allows the plant to keep photosynthetic activity at appropriate levels. Such mechanism would explain the ability of this species to photosynthesize, even when the leaf surface was damaged up to $30 \%$. Under such conditions, grapevine plants can be used as bio-indicators of $\mathrm{F}$ pollution or used in mapping fluorine pollution as earlier suggested by Festy (2003).

The sulphur content was higher in central part of leaf than in control but lower at the margins than in control. These findings suggested that inter-vein central necroses are probably due to $\mathrm{SO}_{2}$, whereas marginal leaf necroses are typical of fluoride compounds effects. Long ago, (Kaiser et al., 1993) fumigated green peas with SO2 or fluorine and found that sulphur is excreted in the root environment as sulphuric acid, while fluorine accumulated in leaf margins. Like other gases, $\mathrm{SO}_{2}$ enters the leaf through the stomata by diffusion process and oxidizes to sulfite $\left(\mathrm{SO}_{3}{ }^{2-}\right)$ and then in sulphate $\left(\mathrm{SO}_{4}{ }^{2-}\right)$ in palisade cell walls (Cape et al., 2003; Eichert and Fernández, 2012). The lesser leaf central necroses in the study area might have been due to low concentration of $\mathrm{SO}_{2}$ or the slow oxidization of $\mathrm{SO}_{3}{ }^{2-}$ to $\mathrm{SO}_{4}{ }^{2-}$ in leaves. These results are similar with some of earlier findings in which it was reported that in humid climate $\mathrm{SO}_{2}$ molecules react with atmospheric water molecules to form more sulphuric acid and greater damages and injuries in leaves than those in arid climate (Ali et al., 2008; Fowler et al., 1989; Freer-Smith and Mansfield, 1987).

In the present study it was found that this local grapevine variety accumulated more calcium in leaf margins to balance fluoride accumulation. These results suggested that grapevine leaves lessen the toxic effects of fluoride by trapping fluoride as $\mathrm{CaF}_{2}$. Long ago, it has been reported that accumulated fluoride as $\mathrm{CaF}_{2}$ do not disturb plant metabolism (Abdallah et al., 2006; Machoy-Mokrzynska, 1995). Our findings confirm the non-translocation of fluoride, through phloem towards lower plant organs as demonstrated in previous works (Wiese et al., 1996). The interaction between fluoride and calcium has also been reported with other cations such as silicon and aluminium (Abdallah et al., 2006; Ben Abdallah et al., 2006; Rhimi et al., 2011). Since magnesium is a central component of the chlorophyll molecule as well as a compound of the cell wall pectin, and in view of its important role in enzyme balance and protein synthesis (Türk et al., 1993), the tendency to considerably increase the Ca content where $\mathrm{F}$ is present and to keep more $\mathrm{Mg}$ in the central leaf parts points to $\mathrm{Mg}$ being involved in a detoxification mechanism that consists in trapping fluoride in the form of $\mathrm{MgF}_{2}$. Both mechanisms allow the plant to maintain its $\mathrm{Ca}$ and $\mathrm{Mg}$ concentrations at appropriate levels to survive under such harsh circumstances. Grapevine accumulated higher amound of phosphorus $(\mathrm{P})$ and $\mathrm{Mg}$ in the central parts of the leaf as a strategy to minimize damage by $\mathrm{F}$ as much as possible. 
In conclusion, necrosis in peripheral regions of grapevine leaf is due to $\mathrm{F}$ toxicity where $\mathrm{F}$ cause damages to epidermal cells, and plants try to lessen the toxic effects of $\mathrm{F}$ by cell deaths at leaf margins while maintaining photosynthetic activity for survival. Moreover, grapevine tolerated $\mathrm{F}$ by increase in cell wall thickening of palisade or spongy cells and by detoxifying $\mathrm{F}$ by accumulating $\mathrm{Ca}$ and $\mathrm{Mg}$ as $\mathrm{CaF}_{2}$ and $\mathrm{MgF}_{2}$.

Acknowledgements. Authors thank M. Abdelhamid Nabli, Emeritus Professor at the Faculty of Sciences of Tunis, for his help in achieving perfectly this work as well as the staff of his laboratory for their technical assistance and data analysis.

\section{REFERENCE}

[1] Abdallah, F. B., Elloumi, N., Mezghani, I., Garrec, J., Boukhris, M. (2006): Industrial fluoride pollution of jerbi grape leaves and the distribution of $\mathrm{F}, \mathrm{Ca}, \mathrm{Mg}$, and $\mathrm{P}$ in them. Fluoride 39: 43.

[2] Ali, S. T., Mahmooduzzafar Abdin, M. Z., Iqbal, M. (2008): Ontogenic changes in foliar features and psoralen content of Psoralea conrylifolia L. exposed to SO2 stress. -Journal of Environmental Biology 29: 661-668.

[3] Azri, C., Tili, A., Serbaji, M. M., Medhioub, K. (2002): Etude des résidus de combustion des fuels liquide et solide et de traitement chimique du phosphate brut dans la ville de Sfax (Tunisie). -Pollution atmosphérique 44: 297-308.

[4] Baillie, C.-K., Kaufholdt, D., Karpinski, L. H., Schreiber, V., Hänsch, S., Evers, C., Bloem, E., Schnug, E., Kreuzwieser, J., Herschbach, C., Rennenberg, H., Mendel, R. R., Hänsch, R. (2016): Detoxification of volcanic sulfur surplus in planta: Three different strategies of survival. -Environmental and Experimental Botany 126: 44-54.

[5] Baunthiyal, M., Bhatt, A., Ranghar, S. (2014): Fluorides and its effects on plant metabolism. -Int J Agric Technol 10: 1-27.

[6] Bell, J. N. B., Treshow, M. (eds.) (2002): Air Pollution and Plant Life John Wiley and Sons. West Sussex, England.

[7] Ben-Abdallah, F., Boukhris, M. (1990): The effect of air pollutants on vegetation in the region of Sfax (Tunisia). -Pollution atmosphérique: 292-297.

[8] Ben Abdallah, F. (2007): Les mécanismes de survie de certaines espèces fruitières dans une zone polluée par le fluor. Université de Sfax, Tunisie.

[9] Ben Abdallah, F., Elloumi, N., Mezghani, I., Boukhris, M., Garrec, J.-P. (2006): Survival strategies of pomegranate and almond trees in a fluoride polluted area. -Comptes Rendus Biologies 329: 200-207.

[10] Blanchar, R., Rehm, G., Caldwell, A. (1965): Sulfur in plant materials by digestion with nitric and perchloric acid. -Soil Science Society of America Journal 29: 71-72.

[11] Cape, J. N., Fowler, D., Davison, A. (2003): Ecological effects of sulfur dioxide, fluorides, and minor air pollutants: recent trends and research needs. -Environment International 29: 201-211.

[12] Chakrabarti, S., Patra, P. K., Mondal, B. (2013): Uptake of fluoride by two paddy (Oryza sativa L.) varieties treated with fluoride-contaminated water. -Paddy and Water Environment 11: 619-623.

[13] Davieson, G., Murray, F., Wilson, S. (1990): Effects of sulphur dioxide and Hydrogen Fluoride singly and in combination on growth and Yield of wheat in open-top chambers. Agriculture, Ecosystems \& Environment 30: 317-325.

[14] Doley, D. (1986): Experimental analysis of fluoride susceptibility of Grapevine (Vitis vinifera L.): Leaf development during four successive seasons of fumigation. -New Phytologist 103: 325-340.

[15] Eichert, T., Fernández, V. (2012): Chapter 4 - Uptake and Release of Elements by Leaves 
and Other Aerial Plant Parts A2 - Marschner, Petra. Marschner's Mineral Nutrition of Higher Plants (Third Edition). Academic Press. San Diego. 71-84.

[16] Eliftheriou, E. P., Tsekos, L. (1991): Fluorides effects on leave cell ultra structure of olive Trees growing in the vicinity of Aluminum Factory in Greece. -Trees 5: 83-89.

[17] Elloumi, N., Ben Abdallah, F., Boukhris, M. (2003): Lead accumulation by a few crops grown in the vicinity of a lead smelter in Sfax. -Air Pollution 178: 285-295.

[18] Festy, B. (2001): About the assessment of human exposure to atmospheric: the need for a global and multi-stakeholder. -Air Pollution 169: 9-12.

[19] Festy, B. (2003): Air pollution phenomena and problems need a comprehensive environmental and health vision. -Air Pollution 178: 237-248.

[20] Fornasiero, R. B. (2001): Phytotoxic effects of fluorides. -Plant Science 161: 979-985.

[21] Fowler, D., Cape, J. N., Deans, J. D., Leith, I. D., Murray, M. B., Smith, R. I., Sheppard, L. J., Unsworth, M. H. (1989): Effects of acid mist on the frost hardiness of red spruce seedlings. -New Phytologist 113: 321-335.

[22] Freer-Smith, P., Mansfield, T. (1987): The combined effects of low temperature and $\mathrm{SO} 2+\mathrm{NO} 2$ pollution on the new season's growth and water relations of Picea sitchensis. New Phytologist 106: 237-250.

[23] Jha, S. K., Nayak, A. K., Sharma, Y. K., Mishra, V. K., Sharma, D. K. (2008): Fluoride Accumulation in Soil and Vegetation in the Vicinity of Brick Fields. -Bulletin of Environmental Contamination and Toxicology 80: 369-373.

[24] Kaiser, W., Höfler, M., Heber, U. (1993): Can plants exposed to SO2 excrete sulfuric acid through the roots? -Physiologia Plantarum 87: 61-67.

[25] Leece, D. R., Scheltema, J. H., Anttonen, T., Weir, R. G. (1986): Fluoride accumulation and toxicity in grapevines Vitis vinifera L. in New South Wales. -Environmental Pollution Series A, Ecological and Biological 40: 145-172.

[26] Locquin, M., Langeron, M. (1978): Manuel de Microscopie edition Masson. 352.

[27] Mabrouk, H., Carbonneau, A. (1996): Une méthode simple de détermination de la surface foliaire de la vigne (Vitis vinifera L.). -Progrès Agricole et Viticole 113: 392-398.

[28] Machoy-Mokrzynska, A. (1995): Fluoride-magnesium interaction. -Fluoride 28: 175177.

[29] Mesquita, G. L., Tanaka, F. a. O., Cantarella, H., Mattos, D. (2010): Atmospheric Absorption of Fluoride by Cultivated Species. Leaf Structural Changes and Plant Growth. -Water, Air, \& Soil Pollution 219: 143-156.

[30] Miller, G. W. (1992): The effect of fluoride on higher plants with special emphasis on early physiological and biochemical disorders. -Fluoride (USA) 26: 3-22.

[31] Murray, F. (1984): Effects of long term exposure to hydrogen fluoride on grapevines. Environmental Pollution Series A, Ecological and Biological 36: 337-349.

[32] Murray, F., Wilson, S. (1988): The joint action of sulphur dioxide and hydrogen fluoride on the yield and quality of wheat and barley. -Environmental Pollution 55: 239-249.

[33] Nicole, M. R., Geiger, J. P., Nandris, D. (1992): Defense of Angiosperm Roots Against Fungal Invasion. -In: BLANCHETTE, R. A.BIGGS, A. R. (eds.) Defense Mechanisms of Woody Plants Against Fungi. Springer Berlin Heidelberg. Berlin, Heidelberg. 181-206.

[34] Rhimi, N., Nasri-Ayachi, M. B., Abdallah, F. B. (2011): The Grape Leaf: a Bioindicator of Fluoride and Sulphur Dioxide Pollution. -International Journal of Sustainable Water and Environmental Systems 3: 69-76.

[35] Sass, J. E. (1958): Botanical microtechnique. 3rd edition. The Iowa state University Press. Ames, lowa, USA.

[36] Stevens, D. P., Mclaughlin, M. J., Alston, A. M. (1998): Phytotoxicity of the fluoride ion and its uptake from solution culture by Avena sativa and Lycopersicon esculentum. -Plant and Soil 200: 119-129.

[37] Telesiński, A., Śnioszek, M., Smolik, B., Malinowska, K., Mikiciuk, M., Cichocka, J., Zakrzewskaa, H. (2011): Fluoride uptake in hydroponic culture by different clones of basket willow, Salix viminalis L. -Fluoride 44: 255-259. 
[38] Türk, S., Gülpen, M., Fink, S. (1993): Aufnahme, Transport und Verbleib von Calcium und Magnesium in Fichten (Picea abies [L.] Karst.) und Kiefern (Pinus silvestris L.) bei unterschiedlicher Ernährung und Schadstoffbelastung. -Forstwiss Centralol 12: 191-208.

[39] Wiese, C., Slovik, S., Kaiser, W. (1996): Wirkungen hoher SO2-kon-zentratimen auf fichte (Picea abies L.karst). -Stechfichte, Waldkiefer und Latshe AFZ.: 570-572.

[40] Zwiazek, J. J., Shay, J. M. (1987): Fluoride-and drought-induced structural alterations of mesophyll and guard cells in cotyledons of jack pine (Pinus banksiana). -Canadian Journal of Botany 65: 2310-2317. 